УДК 94(520).01

ВЛИЯНИЕ БУДДИЗМА НА РАСПРОСТРАНЕНИЕ ПИСЬМЕННОСТИ В ЯМАТО В СЕРЕДИНЕ УІ В. Дмитрий А. Суровень ${ }^{a} @$

\author{
${ }^{a}$ Уральский государственный юридический университет, 620137, Россия, г. Екатеринбург, \\ ул. Комсомольская, 21 \\ @Yamato.ur@mail.ru
}

Поступила в редакиию 07.07.2018. Принята к печати 05.12.2018.

Ключевые слова: древняя Япония, узелковое письмо, резы на дереве, принц Хиронива, Киммэй, Сон-ван

\begin{abstract}
Аннотация: В статье анализируется влияние буддизма, появившегося в Японии в первой половине VI в., на процесс распространения письменности и письменной культуры в Ямато. Установлено, что китайские династийные истории преуменьшают степень распространения письменности в Японии VI в., желая связать ее появление исключительно с заимствованием буддизма, что противоречит находкам древнеяпонских эпиграфических надписей на мечах и зеркалах V в. Путаница в китайских источниках возникла из-за сохранения в начале VI в. древней традиции фиксации, сохранения и передачи информации при помощи узелкового письма и резов на дереве. Появление буддизма в Японии в начале VI в., представление буддизма при дворе непризнанного правителем Ямато принца Хиронива (будущего Киммэя) в 538 г., официальное признание буддизма уже при дворе государя Киммэя в 552 г. (что подтверждается сообщениями китайских династийных историй) привели в Ямато к отказу от практики узелкового письма и резов на дереве и активизации процесса обучения письму в связи с необходимостью чтения буддийской литературы, что послужило причиной усвоения иероглифического письма японскими буддистами и учёными в должной мере, достаточной для составления письменных текстов правильным китайским языком.
\end{abstract}

Для цитирования: Суровень Д. А. Влияние буддизма на распространение письменности в Ямато в середине VI в. // Вестник Кемеровского государственного университета. 2018. № 4. С. 79-92. DOI: https://doi. org/10.21603/2078-8975-2018-4-79-92

\section{Введение}

В первой половине VI в. в Ямато начинает распространяться буддизм [1]. В Японии, как и на всем Дальнем Востоке и в Центральной Азии, буддизму принадлежала исключительная роль в формировании установок на распространение письменного текста в пространстве [2, с. 118]. Знакомство с учением Будды первых адептов этой религии в Японии предполагало овладение китайским языком и, следовательно, приобщение к вполне светским достижениям материковой цивилизации [3, с. 67]. Так как данный вопрос слабо исследован в западной и российской исторической науке, существует необходимость проанализировать материалы источников с тем, чтобы выяснить - как появление буддизма в Ямато повлияло на распространение письменности и письменной культуры в Японии в середине VI в.
Сведения китайских династийных историй о распространении письменности в Японии

В связи с этим следует обратить внимание на такую особенность сведений китайских источников (Бэй-ши, 629; Суй-шу, 630/643), рассказывающих о распространении иероглифической письменности в Ямато. Китай, претендуя на роль центра просвещения и культурности в Восточной Азии, связывал распространение культурных достижений (в том числе и письменности) со своим влиянием. Поэтому с точки зрения китайцев VII в. письменность в Японию могла попасть (при посреднической роли Кореи) только в середине VI в. вместе с буддизмом $[3$, с. 6], центром распространения которого в Восточной Азии был Китай. По этой причине китайские династийные истории сообщают: «Условных письмен (文字 кит. вэ́нь-изы̀ - письменных знаков) не имели, а для памяти вырезывали знаки на дереве и делали узелки на веревочке. Исповедуют будд[и]йский закон. Условные письмена введены с того времени, как получили из Бо-цзи (кор. Пэкче) будд[и]йские 
священные книги» (Суй-шу, гл. 81) [цит. по: 4, с. 96; 5, p. 10; 6, p. 29-30]. «Нет письменных знаков (кит. вэ́нь-иззы̀), только вырезают ${ }^{1}$ [знаки на] дереве [и] завязывают узлы на веревке 2 . [Когда начали] почитать (кит. цзиेн) буддийские законы ${ }^{3}$ в Пэкче [японцы] получили желаемые (кит. цъю́-дэ́) буддийские сутры [в Ямато] начали обладать письменными знаками (кит. вэ́ нь-изъう)》(無レ文字、唯刻レ木・結繩。敬レ佛 法、於 百濟 求得レ佛經、始有レ文字 5 [3, c. 6]) (Суйшу, св. 81-й, дунъи, Во-го). Эту фразу слово в слово повторяет «Бэй-ши» (無レ文字、唯刻レ木・結繩。敬 佛法、於 百濟 求得 佛經、始有 文字 $^{6}$ ) (Бэй-ши, св. 94-й, ле-чжуань, Во).

Источники X-XI вв. не прямо, но также связывали появление письменности в Японии с распространением буддизма. В «Цзю Тан-шу» (945) написано: «Имеют в большом количестве (кит. по̆-ю) письменные знаки (кит. вэ́нь-иззыો), [т. к. (?)] по [их] обычаям почитают закон (кит. фӑ) Будды» (頗 有 レ文字、俗 敬レ 佛法7 [6, p. 38; 5, p. 11]) (Цзю Таншу, св. 199-й, ч. 1-я, дунъи, Вого-Жибэнь). Сходная мысль обозначена в «Танхуйяо» (961): «По их обычаям имеют письменные знаки (кит. вэ́нь-изъџ), [т. к. (?)] почитают закон Будды» (俗 有レ文字。敬 レ佛法 $\left.{ }^{8}\right)$ (Танхуйяо, св. 99-й, Во-го). «Синь Таншу» (1060) добавляется: «Имеют [письменные] знаки (кит. цззй), [т. к. (?)] (издревле) почитают (кит. ша̀н) закон (кит. фӑ) Будды (кит. фи́' mý)» (有 レ字、尚レ浮屠法 9 [6, p. 38; 5, p. 11]) (Синь Тан-шу, св. 220-й, дунъи, Жибэнь).

В связи с этим А. Н. Мещеряков считает, что письменность до середины VI в. (до распространения буддизма) в Японии не получила сколько-нибудь широкого распространения [3, с. 6].

Сходную ситуацию в рассказе о наличии письменности в южнокорейском государстве Силла VI в. мы видим в «Лян-шу» (Истории [династии] Лян [502-557], 637) - М. Н. Пак обратил внимание на то, что китайцы отрицали существование письменности в Силла в VI в. [7, с. 33]. «Не имеют письменных знаков (кит. вэ́нь-изыџ), вырезают [знаки] на дереве (刻 кит. кэे) в качестве письма [на бирках] (кит. сѝнь)» (無文字、刻レ木、為レ信 ${ }^{10}$ ) (Лян-шу, св. 54-й, Синьло). Однако это противоречит данным эпиграфики. Найдены четыре каменные стелы силлаского Чинхын-вана (540-575), датируемые соответственно 555, 561, 568 гг., с текстами на вэньяне; а также камень с надписью периода царствования Чинхын-вана. Создание стел - яркое свидетельство того, что в Силла к середине VI в. литература на китайском языке имела широкое распространение и была важным компонентом письменной культуры корейских государств [8, с. 29-30]. К тому же другой китайский источник - «Бэй-ши», в отличие от «Ляншу», подтверждает наличие письменности в Силла (кит. Синьло): их «синьлоские письмена (кит. вэ́нь-йзbi) <.. > сходны с китайскими» [4, с. 69] (其文字、 $<\ldots>$ 同 於 中國 ${ }^{11}$ ) (Бэй-ши, гл. 94, III. Синьло). Таким образом, явно прослеживается стремление китайцев принизить культурный уровень Силла и степень знакомства «восточных иноземцев» с китайской письменностью.

Возникает вопрос: не делают ли китайцы то же самое и в отношении Ямато? Видимо, да. Заявления китайских источников VII-XI вв. об отсутствии письменности у японцев до принятия буддизма не соответствуют такому факту, как находки в Японии эпиграфических надписей на мечах и зеркалах V в. $[9$, c. $73-74 ; 10$, c. $17 ; 11$, с. $71 ; 12$, c. 106,128 ; 13 , p. $454 ; 14$, p. $24 ; 15$, 頁 $376 ; 16$, 頁 $182-183 ; 17$, 頁84-89; 18, 頁257-282, 362, 415-416; 8, c. 39-40; 19, p. 253,$257 ; 20$, p. 405-420; 21; 頁 54; 22, 頁 318; 23, 頁 13,$15 ; 24$, 頁 $1-4 ; 25$, 頁 $8 ; 26$, 頁 $327 ; 27$, 頁9; 28, 頁43-45; 29, 頁36; 30, 頁89], противоречат сведениям более ранних китайских династийных историй (например, «Сун-шу» (513) и опирающейся на ее материалы «Нань-ши» (629)), сообщающих о переписке китайских императоров V в. с правителями

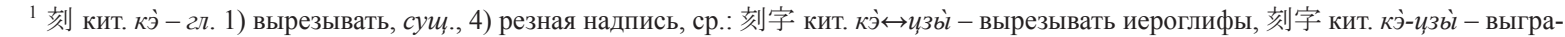
вированная надпись; 刻文 кит. кэे-вэ́нь - археол. резная надпись (БКРС, II, с. 1028, 1029). (Здесь и далее по тексту перевод приводится по Большому китайско-русскому словарю (БКРС). М.: Наука, 1983. T. I-IV с указанием тома и страниц).

2 結繩 кит. изе́-шэ́н - древний способ запоминания текущих дел, вместо письма (БКРС, II, с. 462-463).

3 佛法 кит. фо́фӑ - досл. будд. «все дхармы, [познанные Буддой]»; буддизм (БКРС, III, с. 549).

4 佛經 кит. фо́изйн (БКРС, III, с. 548).

5 隋書 (二十四史全譯). 上海: 漢語大詞典出版社, 2004. 第二册. 頁1653. (Sui-shu (Er shi si shi quan yi). Shanghai: Han-yü dacidian chubanshe, 2004. Vol. II. P. 1653)

6 北史 (二十四史全譯). 上海: 漢語大詞典出版社, 2004. 册四册. 頁2563. (Bei-shi (Er shi si shi quan yi). Shanghai: Han-yü dacidian chubanshe, 2004. Vol. IV. P. 2563).

7 舊唐書 (二十四史全譯). 上海: 漢語大詞典出版社, 2004. 第六册. 頁4594. (Jiu Tang-shu (Er shi si shi quan yi). Shanghai: Han yü dacidian chubanshe, 2004. Vol. VI. P. 4594)

8 唐會要. 上海: 中華書局出版, 1955. 頁1764. (Tanghuiyao. Shanghai: Zhonghua shujü chuban, 1955. P. 1764).

9 新唐書 (二十四史全譯). 上海: 漢語大詞典出版社, 2004. 第八册. 頁4755. (Xin Tang-shu (Er shi si shi quan yi). Shanghai: Han-yü dacidian chubanshe, 2004. Vol. VIII. P. 4755)

10 信 кит. сѝнь - сущ. 1) письмо, 4) верительный знак, бирка (БКРС, II, c. 440); 梁書 (二十四史全譯). 上海: 漢語大詞典出版社, 2004. 頁729. (Liang-shu (Er shi si shi quan yi). Shanghai: Han-yü dacidian chubanshe, 2004. P. 729).

11 北史 (二十四史全譯). 上海: 漢語大詞典出版社, 2004. 第四册. 頁2551. (Bei-shi (Er shi si shi quan yi). Shanghai: Han-yü dacidian chubanshe, 2004. Vol. IV. P. 2551). 
Ямато [31-33]. Материалы корейских источников свидетельствуют о том, что письменность в государстве Ямато (по крайней мере в дипломатической деятельности: 倭王 移書 絕交 ${ }^{12}-$ «В тридцать шестом году $(345)<\ldots>$ во втором месяце вэский ван ${ }^{13}$ прислал письмо о разрыве отношений» [34, с. 107]; 二 月、倭 移書 新羅 絕交 ${ }^{14}-$ «во втором месяце вэский ван прислал письмо о разрыве отношений» ${ }^{15}$ ) начала использоваться в середине [35] - второй половине IV в. [36]. С начала V в. китайская письменность стала более широко распространяться в Японии [31; 32].

Традиционные способы фиксации, сохранения и передачи информации в Японии

Но сведения японских источников показывают, что наряду с использованием иероглифической письменности, носителями которой прежде всего были переселенцы с материка [31; 32], японцы сохраняли древнюю традицию передачи информации при помощи узелкового письма и резов на дереве (что подтверждает сообщения китайских династийных историй) до начала VI в.

Путаница в китайских источниках, видимо, возникла по причине того, что, как сообщается в «Нитю̄-рэки» (нач. XIV - cep. XV вв. ${ }^{16}$ ), в 478-517 гг. была частично возобновлена древняя практика передачи информации при помощи узелкового письма и резов на дереве ${ }^{17}$ [37, 頁 52]. В «Ни-тю̄-рэки» написано: как указывают комментаторы, начиная с 478 г. «на протяжении 39-ти лет ${ }^{18}$ не было названий (яп. го̄) [годов], не записывали "земные ветви" [знаки двенадцатеричного цикла] [и] "небесные стволы" [знаки десятеричного цикла] (яп. сикан), в этот период [вместо письма] завязывали узлы на веревке (яп. кэиу-дзё, кит. иззе́-шэ́н) [и] вырезали (刻 кит. кэे, яп. кидзамэтэ) [знаки на] дереве, чтобы содействовать (придать совершенный характер) управлению» (井九年 無レ號、不記レ支干、其間 結レ縄刻レ木 以成政 ${ }^{19}$ [38, 頁 $36 ; 37$, 頁52]). Пo- лучается, что в 517 г. (год хиното-тори, 34-й год цикла $)^{20}[38$, 頁 36; 37, 頁52] вместо традиционных способов фиксации, сохранения и передачи информации при помощи узелкового письма и резов на деревянных дощечках вернулись к практике использования иероглифов для летосчисления и фиксации событий (как мы это видим на эпиграфических надписях V в.: 治天下㙏(蝮) 口ם 歯 大王世 [цит. по: 29, 頁36; 22, 頁318; 23, 頁318; 19, p. 257, n. 4]; 矣(癸)未年、八月。曰十大王年 [цит. по: 18, 頁 420; 19, p. 254, п. 5] (ср. перевод [19, p. 253-254, 3, n. $2 ; 39$, c. 17]); 辛亥年、七月中記。<..> 獲加多 支图 大王 寺 在レ 斯鬼宮 時 [цит. по: 18 , 頁 $362 ; 38$, p. $20 ; 9$, c. 73-74; 11, c 70-71]).

\section{Распространение буддизма в Ямато}

В царствование пэкческого правителя Сон-вана (523-554) между Пэкче и Японией существовали тесные культурные связи. Сон-ван присылал в Японию пэкческих техников и специалистов по медицине, астрономии, астрологии и конфуцианским канонам (некоторые из них - интеллектуалы китайского происхождения) [40, с. 138] (подробнее см. [39]). Именно в правление Сон-вана (и, скоpeе всего, через пэкческие официальные миссии) японцы начали заимствовать у Пэкче буддийские идеи и ритуальные предметы, что положило начало распространению буддийской религии на Японских островах [40, с. $138 ; 41$, р. 12]. С Сон-ваном связана история официального принятия буддизма при дворе Ямато в царствование государя Киммэя (539/540571). По сведениям «Ганго̄дзи гаран энги», «Дзёгу Сётоку хо̄о̄ тэйсэцу» и «Сёдзан-энги» [42, с. 216] принятие буддизма при дворе Ямато произошло в $538 г_{.}^{21}[43$, с. $68 ; 44$, с. 216,476 , п. $7 ; 45$, 頁 125$]$, а по сведениям «Нихон-сёки» - в 552 г. [46, с. 53].

В храмовой хронике «Гангордзи гаран энги» (составление которой началось в 613 г.) утверждается, что «Закон Будды ведет свое начало в стране

\footnotetext{
12 三國史記. 巻第. 京城: 朝鮮史学会, 1928. 第二. 頁10. (Samkuk sagi, 1th-50th scrolls. Seoul: Choson sahak-hwe, 1928. Part 2. P. 10).

13 т.е. правитель Ямато.

14 書 кор. со, кит. $и \overline{-}$ - 2) письмо; послание, 3) акт, документ, бумага; письменный приказ (БКРС, II, с. 552).

15 東國通鑑, 巻之四・五. 東京: 出雲寺松柏堂, 1883. 三冊. 頁一b. (Tongguk tonggam, 4th - 5th scrolls. Tōkyō: Izumo-ji shōhaku-dō, 1883. Book 3. P. 1 b).

16 逸年号史料 (Kawanishi Yoshihiro. Itsu nengō shiryō). Режим доступа: http://www2.odn.ne.jp/ cbe66980/ Main/NENGO01.htm (дата обращения: 28.05.2018); 大宝以前の逸年号一逸年号史料集成 (Kawanishi Yoshihiro. Taihō-izen-no itsu nengō shiryō shūsei). Peжим доступа: http://www2.odn.ne.jp/ cbe66980/Main/Appendix.htm (дата обращения: 28.05.2018).

17 二中歴 // 史籍集覧. 東京: 近藤出版部, 1926. 第二十三冊. 頁36. (Ni-chū-reki // Shiseki shūran. Tōkyō: Kondō shuppanbu, 1926. Vol. 23. P. 36); 大宝以前の逸年号一逸年号史料集成 (Kawanishi Yoshihiro. Taihō-izen-no itsu nengō shiryō shūsei). Peжим доступа: http:// www2.odn.ne.jp/ cbe66980/Main/Appendix.htm (дата обращения: 28.05.2018).

18 年始ヨリ三十九年間, т. е. до 517 г. [37, c. 52].

19 大宝以前の逸年号-逸年号史料集成 (Kawanishi Yoshihiro. Taihō-izen-no itsu nengō shiryō shūsei). Режим доступа: http://www2. odn.ne.jp/ cbe66980/Main/Appendix.htm (дата обращения: 28.05.2018).

20 逸年号史料 (Kawanishi Yoshihiro. Itsu nengō shiryō). Режим доступа: http://www2.odn.ne.jp/ cbe66980/ Main/NENGO01.htm (дата обращения: 28.05.2018).

21 元興寺伽藍縁起. 大日本仏教全書. 東京: 仏書刊行会, 1922. 第118巻. 頁138. (Gangōji garan engi. Dai-nihon bukkyō zensho. Tōkyō:
} Bussho kankōkai, 1922. Vol. 118. P. 138). 
Ямато с 12-й луны 538 года ${ }^{22}$, когда прошло семь лет $^{23}$ с тех пор, как император Амэ-куни-оси-харуки Хиронива ${ }^{24}$ стал повелевать Поднебесной из дворца Сикисима. А служил ему тогда главный министр по имени Сога-но оми Инамэ-но сукунэ ${ }^{25}$ » [47, c. 416] (大倭國佛法 創 ${ }^{\vee}$ 自 斯歸嶋宮治天下 天 國案春岐廣庭天皇ノ御世、蘇我大臣稻目宿禰 仕奉 時。治天下七年、歳次 戊午 十二月 度來 $\left.{ }^{26}\right)$ (Ганго̄дзи гаран энги, Хиронива).

Проблема датировки 538 г. заключается в том, что предыдущий государь - Кэйтай - по официальной хронологии скончался в 531 г. [46, с. 23], с 531 по 534 гг. на троне не было правителя, законный наследник Кэйтая - принц Хиронива [46, с. 9] (будущий Киммэй) - пришел к власти только в конце 539 г., а 1-м годом его царствования считается 540 г. [46, с. 33]. Естественно, этот период междуцарствия 531-534 гг. привлек внимание исследователей. М. В. Воробьев полагал, что после смерти Кэйтая в 531 г. стараниями клана Сога сын Кэйтая от его главной жены (государыни) Тасирага-но микото (дочери Нинкэна) - принц Хиронива (Киммэй) [48, с. 209] был выдвинут на престол [43, с. 69], но он остался не признанным кланом О̄томо [49, с. 113].

Поэтому именно молодой принц Хиронива (508 г. рожд., т. е. 23-х лет отроду $\left.{ }^{27}\right)$ и был правителем Ямато в 532-533 гг. (о чем сообщается в «Ганго̄дзи гаран энги», относя 1-й год правления Киммэя к 532 г. ${ }^{28}[47$, c. 416]). Однако, видимо, это не устраивало старших единокровных братьев принца Хиронива (от первой супруги Кэйтая, которую он взял в жены еще до своего вступления на престол [46, с. 302, п. 21]). Принц крови Магари-но О̄э (будущий государь Анкан, 534-535) и принц крови Хинокума-но Таката (будущий государь Сэнка, 536-539) [46, с. 10, 302, п. 23, $24]$ - за спиной которых стояли кланы О̄томо-но $м y$ радзи [49, с. 113] и Мононобэ-но мурадзи - сами претендовали на пост главы государства Ямато. Так, в «Кодзики» (св. 3-й) в конце раздела «Кэйтай-ки» есть абзац, где перечислены будущие правители в интересной последовательности: сначала государством правил (получается с 532 г.) принц Амэ-куни
Оси-харуки Хиронива (будущий государь Киммэй, 540-571), потом царствовал Хирокуни Оситакэ Канахи (Анкан, 534-535), а затем Такэво Хирокуни Оситатэ (Сэнка, 536-539) [48, с. 210]. Таким образом, клан О̄томо, не признав принца Хиронива государем Ямато, в 534 г. поставил у власти Анкана (534-535), а затем Сэнка (536-539). Получается (делает вывод М. В. Воробьев), что в Ямато между 531-539 гг. (в 534-535 гг. - Хиронива и Анкан; и в 536-539 гг. - Хиронива и Сэнка) было два правителя одновременно [49, с. 113]. Таким образом, первый составитель «Ганго̄дзи гаран энги» - принц Умаядо - использовал какой-то первоисточник, автор которого был сторонником наследственных прав на трон именно принца Хиронива (Киммэя), поэтому он вел счет годам его царствования с 532 г., а не с конца 539 г., как это происходит в официальной хронологии (использованной в «Нихон-сёки»). Поэтому-то 538 год и назван в «Ганго̄дзи гаран энги» 7-м годом правления государя Киммэя.

О начале распространения буддизма при дворе Ямато, как считают А. Н. Игнатович и Ричард Боуринг, именно в 538 г. [43, с. 69; 41, р. 17] в «Ганго̄дзи гаран энги» сообщается: «Во времена правления вана Пэкче по имени Сонмён ${ }^{29}$ преподнес он [императору Киммэю] изображение принца Сиддхартхи ${ }^{30}$, сосуд для возлияния священной воды на изображение Будды, футляр со свитком, повествующим о начале Закона Будды. [В послании вана] говорилось: «Истинно ведаю: закон Будды превосходит все другие учения. Следует исповедать его и в этой стране»» [47, с. 416] (百濟國ノ聖明王ノ時、太子像 并 灌 佛之器一具及説佛起書卷一筐度而言: 『當聞、佛 法 既是世間 無上之法。其國亦應修行也』31) (Ганго̄дзи гаран энги, Хиронива).

Датировка 538 г. повторена в «Дзёгӯ Сётоку хо̄ō тэйсэцу» (кон. VII - нач. VIII вв.): «В царствование государя [Киммэя управлявшего Поднебесной из дворца] Сикисима, в год иутиноэ-ума (55-й год цикла) [538], 10-я луна, 12-й день, государь [страны] Кудара (кор. Пэкче) [Сон]мён-ван впервые переправил [в Японию] статую Будды, буддийские сутры,

22 戊午 иутиноэ-ума, 55-го года цикла (元興寺伽藍縁起. 大日本仏教全書. 東京: 仏書刊行会, 1922. 第118巻. 頁138 (Gangōji garan engi. Dai-nihon bukkyō zensho. Tōkyō: Bussho kankōkai, 1922. Vol. 118. Р. 138)) [47, c. 424, п. 2; 37, 頁 52].

23 Киммэй официально занимал престол с 539/540 по 571 гг. [46, с. 33, 68]; таким образом, хронология «Гангордзи гаран энги» разошлась с официальной хронологией [47, с. 425, п. 7].

24 др.-яп. Пиронипа, т.е. Киммэй [47, с. 425, п. 7].

$25506[?]-570$ гг. жизни.

26 元興寺伽藍縁起. 大日本仏教全書. 東京: 仏書刊行会, 1922. 第118巻. 頁138. (Gangōji garan engi. Dai-nihon bukkyō zensho. Tōkyō: Bussho kankōkai, 1922. Vol. 118. P. 138).

${ }^{27}$ Киммэй умер в 571 г. в возрасте 63 лет; 571 г. -63 года $=508$ год рождения [46, с. 68, 316, п. 174; 48, с. 238, п. 186].

28 元興寺伽藍縁起. 大日本仏教全書. 東京: 仏書刊行会, 1922. 第118巻. 頁138. (Gangōji garan engi. Dai-nihon bukkyō zensho. Tōkyō: Bussho kankōkai, 1922. Vol. 118. P. 138)

29 523-554 гг. правления [36, с. 171-173].

${ }^{30}$ прижизненное имя Будды Шакьямуни [47, с. 425, п. 10].

31 元興寺伽藍縁起. 大日本仏教全書. 東京: 仏書刊行会, 1922. 第118巻. 頁138. (Gangōji garan engi. Dai-nihon bukkyō zensho. Tōkyō: Bussho kankōkai, 1922. Vol. 118. P. 138). 
буддийское учение (правила поведения) вместе с монахами. Было приказано [их] предоставить [сановнику] Сога-но Инамэ-но сукунэ о̄-оми, предписав [ему], [чтобы буддийское учение] процветало» (志癸嶋ノ天皇ノ御世、戊午年、十月、十二日、百濟 國ノ主 (聖) 明王、始 奉度レ佛像 経 教 并 僧等、 敕授レ蘇我ノ稲目ノ宿穪ノ大臣 令レ興隆也 也 $^{32}$ [цит. по: 45, 頁 $125 ; 37$, 頁 52]) (Дзёгӯ Сётоку хо̄о̄ тэйсэцу, Киммэй, год иутиноэ-ума, 10-я луна, 12-й день).

С появлением в Японии буддизма древняя практика передачи информации при помощи узелкового письма и резов была прекращена, т. к. окончательно утвердилось использование иероглифов ${ }^{33}$. Когда Киммэй бесповоротно взошел на трон в конце 539 г., как сообщает «Мунаката дай-босацу го-энги» (источник конца периода Камакура): «В 5-й год $C \bar{m} \overline{\bar{e}}$ [540 г.] царствования императора (сумэра-микото) Киммэя 30-го поколения человеческих государей (яп. хйто-но кими) из государства Сираги-но куни (кор. Силла-кук) поднесли статую Шакья[муни] из позолоченной бронзы» (人王ノ井 代ノ欽明天皇/御宇ノ僧聴ノ五年仁、自 新羅国 献 レ釈迦ノ金銅像 ${ }^{34}$ ) (Мунаката дай-босацу го-энги, Киммэй, Со̄mё, 5-й год). В «Нихон-сёки» это посольство датируется 8-й луной 1-го года правления Киммэя (540) [46, с. 33]. А далее в «Мунаката дай-босацу го-энги» сообщается: «1-й год Мэйё 【год мидзуното-и (60-й год цикла) [543 г.] (明要 яп. Мэйё-досл. «ясная суть»; некоторые комментаторы текста 1-й год Мэйё датируют не 541 г., а 543 г.: 明 要元年 $\left.(543)^{35}\right)$ (д. б. 541 г.) (однако по сообщению пяти источников: «Ни-тю̄-рэки», «Рэйкики сисё», «Нёдзэ-ин нэндай-ки», «Со-куни гидзэнко̄» и «Бо̄со̄ ман-року» - 1-й год Мэйё приходится на 541 г. (год каното-тори 辛西, 58-й год цикла): 明要【元 辛 西】 ${ }^{36}$; 明要 (辛西) ${ }^{37}$; 【辛西】明要元 ${ }^{38}$ ), 2-й год правления Киммэя (明要 (欽明帝ノ二年、辛西 ${ }^{39}$ ); 【辛西】 二[年] 明要元 $\left.{ }^{40}\right) 】$ прекратили (停 яп. томаритэ [50, c. 81] (БКРС, с. II, с. 1044)) завязывать [вместо письма] узлы на веревке (яп. кэцу-дзё, кит. изе́-шэ́н) [и] вырезать (яп. кидзамэтэ) [знаки на] дереве, и тогда только начали правильно выражать письменно ${ }^{41}$ иероглифы» (明要元年【癸亥】停レ結縄、刻レ木。始 成レ文字 ${ }^{42}$ ) (Мунаката дай-босацу го-энги, Киммэй, Мэйё, 1-й год). Сходная информация содержится в «Нитю̄-рэки»: «[Девиз правления] Мэйё [продолжительностью] одиннадцать лет (начало эры [приходится на] год каното-тори, 58-й знак цикла [541г.], [когда] официальные документы (яп. бунсён ${ }^{43}$ начали появляться (яп. дэкитэ ${ }^{44}$, узелковое письмо (яп. кэиу-дзё, кит. изе́-цэ́н) и резы на дереве остановились / закончились» (明要十一年【元辛西 [541]、文書 始出 来、結縄刻木 止畢】 ${ }^{45}$ ) (Ни-тю̄-рэки, Мэйё, 1-й год). Таким образом, распространение буддизма привело

32 上宮聖徳法王帝説. 古事記・上宮聖徳法王帝説・祝詞. 東京: 日本古典全集刊行会壽梓, 1933. 頁25. (Jōgū Shōtoku hōō teisetsu. Kojiki, Jōgū Shōtoku hōō teisetsu, norito. Tōkyō: Nihon koten zenshū kankō-kai jushi, 1933. P. 25); 上宮聖徳法王帝説. 聖徳太子御伝叢書. 東京: 金尾文淵堂, 1942. 頁47. (Jōgū Shōtoku hōō teisetsu. Shōtoku-taishi go-den sōsho. Tōkyō: Kanao bun'endō, 1942. P. 47).

33 大宝以前の逸年号-逸年号史料集成 (Kawanishi Yoshihiro. Taihō-izen-no itsu nengō shiryō shūsei). Режим доступа: http://www2. odn.ne.jp/ cbe66980/Main/Appendix.htm (дата обращения: 28.05.2018).

34 宗像大菩薩御縁起. 宗像郡誌. 中編. 若松: 深田千太郎, 1944. 頁376. (Munakata daibosatsu go-engi. Munakata-gun-shi. Vol. 2. Wakamatsu: Fukada Sentarō, 1944. P. 376); 大宝以前の逸年号-逸年号史料集成 (Kawanishi Yoshihiro. Taihō-izen-no itsu nengō shiryō shūsei). Режим доступа: http://www2.odn.ne.jp/ cbe66980/Main/Appendix.htm (дата обращения: 28.05.2018).

35 大宝以前の逸年号-逸年号史料集成 (Kawanishi Yoshihiro. Taihō-izen-no itsu nengō shiryō shūsei). Режим доступа: http://www2. odn.ne.jp/ cbe66980/Main/Appendix.htm (дата обращения: 28.05.2018).

36 二中歴. 史籍集覧. 東京: 近藤出版部, 1926. 第二十三冊. 頁36. (Ni-chū-reki. Shiseki shūran. Tōkyō: Kondō shuppanbu, 1926. Vol. 23. P. 36).

37 茅空漫録. 日本經濟叢書. 東京: 日本經濟叢書, 1917. 巻十九. 頁57. (Bōsō man-roku. Nihon keizai sōsho. Tōkyō: Nihon keizai sōsho kankō-kai, 1917. Vol. 19. P. 57).

38 如是院年代記. 群書類従. 東京: 経済䧱誌社, 1893. 第拾七輯. 頁862. (Nyoze-in nendai-ki. Gunsho ruijū. Tōkyō: Keizai zasshi-sha, 1893. Iss. 17. P. 862); 如是院年代記. 群書類従. 東京: 経济䧱誌社, 1902. 第十六輯. 頁862. (Nyoze-in nendai-ki. Gunsho ruijū. Tōkyōo: Keizai zasshi-sha, 1902. Iss. 16. P. 862); 如是院年代記. 新校 群書類従. 東京: 内外書籍, 1937. 第二十巻. 頁251. (Nyoze-in nendai-ki. Shinkō gunsho ruijū. Tōkyō: Naigai shoseki, 1937. Vol. 20. P. 251); 大宝以前の逸年号-逸年号史料集成 (Kawanishi Yoshihiro. Taihō-izenno itsu nengō shiryō shūsei). Режим доступа: http://www2.odn.ne.jp/ cbe66980/Main/Appendix.htm (дата обращения: 28.05.2018).

39 宗像大菩薩御縁起. 宗像郡誌. 中編. 若松: 深田千太郎, 1944. 頁57. (Munakata daibosatsu go-engi. Munakata-gun-shi. Vol. 2. Wakamatsu: Fukada Sentarō, 1944. P. 57).

40 如是院年代記. 群書類従. 東京: 経済䧱誌社, 1893. 第拾七輯. 頁862. (Nyoze-in nendai-ki. Gunsho ruijū. Tōkyō: Keizai zasshi-sha, 1893. Iss. 17. P. 862); 如是院年代記. 群書類従. 東京: 経済雑誌社, 1902. 第十六輯. 頁862. (Nyoze-in nendai-ki. Gunsho ruijū. Tōkyō: Keizai zasshi-sha, 1902. Iss. 16. P. 862); 如是院年代記. 新校 群書類従. 東京: 内外書籍, 1937. 第二十巻. 頁251. (Nyoze-in nendai-ki. Shinkō gunsho ruijū. Tōkyō: Naigai shoseki, 1937. Vol. 20. P. 251).

$41 \mathrm{cp}$. 成文 яп. сэйбун, кит. чэ́нвэ́нь́-2) сформулировать на бумаге, правильно выразить письменно (БКРС, IV, с. 256).

42 宗像大菩薩御縁起. 宗像郡誌. 中編. 若松: 深田千太郎, 1944. 頁376. (Munakata daibosatsu go-engi. Munakata-gun-shi. Vol. 2. Wakamatsu: Fukada Sentarō, 1944. P. 376); 大宝以前の逸年号一逸年号史料集成 (Kawanishi Yoshihiro. Taihō-izen-no itsu nengō shiryō shūsei). Режим доступа: http://www2.odn.ne.jp/ cbe66980/Main/Appendix.htm (дата обращения: 28.05.2018).

43 文書 яп. бунсё, кит. вэ́нь́му (mì) - 1) официальный документ; казенная бумага; служебное письмо (БКРС, IV, с. 60).

44 出来 $в м$. 出來 яп. дэкиру, кит. чу্’ла́й - 1) выходить наружу, 2) вылезать (БКРС, ІІ, с. 389).

45 二中歴. 史籍集覽. 東京: 近藤出版部, 1926. 第二十三冊. 頁36. (Ni-chū-reki. Shiseki shūran. Tōkyō: Kondō shuppanbu, 1926. Vol. 23. P. 36); 大宝以前の逸年号-逸年号史料集成 (Kawanishi Yoshihiro. Taihō-izen-no itsu nengō shiryō shūsei). Режим доступа: http:// www2.odn.ne.jp/ cbe66980/Main/Appendix.htm (дата обращения: 28.05.2018). 
к тому, что при дворе Ямато овладели письменностью в должной мере, в результате чего старые способы фиксации и передачи информации стали не нужны по этой причине узелковое письмо и резы на дереве вышли из употребления. Видимо, вместо вырезания знаков на дереве стали писать эти знаки тушью на деревянных дощечках [51, с. 186-187]. В связи с этим исследователи отмечают, что к середине VI в. двор Ямато использовал письменные записи для того, чтобы улучшить ведение административных дел и, таким образом, расширить и укрепить свой политический контроль [13, p. 311], и для ведения международной деятельности. В этот период между японским и пэкческим двором осуществлялась активная переписка. Так, в 10-й день 2-й луны 550 г. государь Киммэй отправил в Пэкче повеление (письмо), приведенное в «Нихон-сёки» ${ }^{46}[46$, c. $51-52 ; 19$, p. $118 ; 52$, p. 64].

В 552 г. в Южной Корее возникла сложная ситуация. Силласцы еще до полного подчинения всех земель Кая (это произойдет в 562 г.), уже в 552 г. (заручившись поддержкой просилланской группировки в Кая) провозгласили себя хозяевами каяских территорий, что фактически означало объявление войны Пэкче, также претендовавшему на эти земли [53, с. 157]. Это вызвало беспокойство у правителей Пэкче, Тэгая (яп. Кара) и Ара-Кая. После разгрома Когурё единственной страной, которая могла бы попытаться остановить агрессию Силла, по мнению этих правителей, была Япония. Кроме того, как сообщают «Нихон-сёки» и подтверждает «Самгук-юса» [53, с. 220, п. 52], выяснилось, что Силла в нарушение соглашений с Пэкче заключила тайный союз с Когурё, направленный против Пэкче $[40$, с. 139,146$]$. Поэтому в 8-й день 5-й луны 552 г. из Южной Кореи в Ямато прибыло объединенное посольство этих трех государств с просьбой о помощи $[53$, с. 97,220 , п. 52; 546, с. 52]. Отвечая на прошение корейцев, Киммэй еще раз подтвердил свою верность союзу с Пэкче, пообещав помощь [46, с. 52; 53, с. 157].

В 552 г. войско из Ямато в Корею еще не прибыло. Чтобы добиться более скорой присылки помощи и упрочить союз с Ямато, Сон-ван в 10-й луне 13-го года правления Киммэя (552) прислал буддийские дары: буддийскую литературу, культовую утварь, а его посланники познакомили двор Ямато с буддизмом ${ }^{47}[43$, с. $69 ; 3$, с. 58-59; 53, с. 157]. Дипломатический замысел Сон-вана заключался в использовании японской помощи для дальнейшей экспансии в северокаяские регионы и активной борьбы против Когурё [40, с. 138; 41, p. 12].

В японской хронике «Нэндай-ки» (984), цитируемой в «Сун-ши», дата 552 г. как года официального принятия буддизма при дворе Ямато подтверждается. «Ама-куни Осихараки Хиронива-но сумэра-микото, еще именуют Киммэй-тэн$н \bar{o}$, в 13-й год от вступления на престол (в 540 г.), циклический год жэнь-шэнь (яп. мидзуноэ-сару, 9-й год цикла) (552 г. [54, с. 134]) - впервые передали Закон Будды из государства Боцзи (кор. Пэкче-кук). [Данный год] выпадает в этой земле на 1-й год Чэ́н-шэ́н (552 г. (БКРС, I, с. 157)) династии Лян» (其《年代記»所記云：『天國排開廣庭 天皇、亦名レ欽明天皇。即位十三年 壬申歳、始 傳 レ佛法於百濟國、當レ此土 梁/承聖元年』 $\left.{ }^{48}\right)(\mathrm{Cун}-$ ши, св. 491-й, Жибэнь-го, [«Нэндай-ки»], год жэньшэнь (552), 1-й год Чэ́н-шэ́н (552)).

«Нихон-сёки» о событиях 552 г. сообщает, что в 10-й луне из Пэкче были присланы статуя Будды, сутры и другие предметы буддийского культа [46, c. $53 ; 40$, с. 138]. «Зимой в 10-ю луну [ван] Пэкче Сонм[ё]н, также называемый $[в а н] \mathrm{Coн,} \mathrm{послал}$ ([человека] из рода [46, с. 53]) Хи-си из Западного округа $<\ldots>$ тальсоля Ноиса Чхикье и других, [которые] преподнесли [императору] статую [46, c. 53] Будды Шакья[муни] из золота [с] мед[дью], несколько стягов ${ }^{49}$ и зонтов ${ }^{50}$, несколько свитков сутр (и шастр $\left.{ }^{51}\right)$. В отдельной записке ${ }^{52}$ [Сонмён] воздал хвалу распространению [Закона ${ }^{53}$ и и прославил [его] достоинства» [цит. по: 47, с. 361; 46, c. $53 ; 19$, p. $119 ; 52$, р. 65]. Записка (объемом около сотни слов $[46$, с. $53 ; 47$, с. 361]) была прочитана государю Киммэю: «В тот день император, дослушав [содержание «Записки»], возрадовался» [47, с. $361 ; 46$, с. 53]. Это же событие упомянуто в указе от 8-го дня 8-й луны 645 года: «На 13-м году правления Поднебесной государем ${ }^{54}$ из дворца Си-

${ }^{46}$ 日本書紀 (国史大系). 東京: 吉川弘文館, 1957. 第一部、第2巻. 頁75. (Nihon-shoki (Kokushi-taikei). Tōkyō: Yoshikawa kobunkan, 1957. Part I. Vol. II. P. 75).

47 元興寺伽藍縁起. 大日本仏教全書. 東京: 仏書刊行会, 1922. 第118巻. 頁12, 15. (Gangōji garan engi. Dai-nihon bukkyō zensho. Tōkyō: Bussho kankōkai, 1922. Vol. 118. P. 12, 15).

48 宋史 (二十四史全譯).上海: 漢語大詞典出版社, 2004. 第十六册. 頁10487. (Song-shi (Er shi si shi quan yi). Shanghai: Han yü dacidian chubanshe, 2004. Vol. XVI. P. 10487).

49 стяги, которые вывешивались на крыше буддийских храмов и внутри них в качестве символа мудрости и добродетели будд и бодхисатв [46, с. 313, п. 95].

${ }^{50}$ шелковые зонты с длинной ручкой, использовавшиеся в церемониях с участием государя и высшей знати [46, с. 313 , п. 96].

51 經論 (Nihon-shoki, p. 77) [19, p. 119], где 經 кит. изйн-будд. Сутра, 經論律 сутры, шастры и виная (БКРС, II, с. 86).

52 別表 досл. отдельном докладе, где 表 яп. хё, кит. бяо - официальный документ (меморандум), доклад (БКРС, III, 884).

${ }^{53}$ т.е. учения Будды [46, с. 53].

${ }^{54}$ Киммэем [46, с. 342, п. 34]. 
кисима (т.е. в 552 г.), ван Мён из Пэкче передал государю Ямато Закон Будды» [46, с. 145-146]. В «Нихон-рёики» сказано: «Внутренние же писания $^{55}$ доставили в правление государя Киммэй, который повелевал Поднебесной из дворца Канадзаси, что в Сикисима» [55, с. 33] (磯城)金刺宮二 御宇 欽明天皇ノ代、内典 來 也56) (Нихон-рёики, св. 1-й, Предисловие).

«Фусо̄-рякки» также рассказывает о событиях 552 г.: Киммэй, 13-й год, «10-я луна, правитель Пэкче [Сон]мён-ван поднёс статую будды Амида ${ }^{57}$ 【высотой 1 сяку 5 сун (ок. 45 см)】, статую Канъон сэйси («мощи достигшей») $)^{58}$ 【высотой 1 сяку (ок. 30 см)】. В докладе (表 яп. хё) говорилось: «[Пусть] услышат министры, [что] среди множества (букв. десяти тысяч) законов, Закон Будды самый лучший. [Из всех] учений этого мира, Закон Будды - превыше всего». Государь [Ямато] (сумэpa-микото), Его Величество (кит. бѝся̀, яп. хэйка), тоже должен изучать буддийскую веру (яп. сюгё, кит. сю̄сúн). Поэтому благоговейно приняли статуи Будды, сутры, учителей (яп. хо̄сu) (религиозной) доктрины, вкупе посол поднес дань. Должно [было] уверовать [в Закон Будды] и взяться за осуществление [его] на практике (как адепты [буддизмa])» (十月、百濟明王 獻レ阿爾陀佛像【長一尺五 寸】、觀音勢至像【長一尺】。表 云：『臣 聞：萬法之 中、佛法最善。世間之道、佛法最上。天皇陛下、亦 應 修行。』故敬捧レ佛像。經 教法師, 附使貢獻。 宜信行者 ${ }^{59}$ ).

В надписи «Дзёроку ко̄мэй» 609 г. (?), сделанной на изображении Будды высотой в шесть дзё из храма Ганго̄-дзи (цитируемой в «Ганго̄дзи гаран энги»), об этом написано: «В правление императора (сумэра-микото) по имени Хиронива (Киммэя), пребывавшего во дворце Сикисима, ван страны Пэкче по имени Мён (он же Сонмён-ван [46, с. 426, п. 46]) сообщил императору: «Пусть услышат министры, что Закон Будды из всех Законов - наилучший. Император также должен почитать его». Ван отправил императору изображения будд, сутры и учителей Закона. Император повелел великому министру Сога по имени Инамэ почитать этот Закон. Так впервые на земле Ямато был утверждён Закон Будды» [цит. по: 46, с. 424] (丈六光銘 曰: 天 皇 名レ廣庭、在レ斯歸斯麻宮 時、百濟ノ明王上 啓：『臣 聞、所謂レ佛法 既是世間 無上之法、天 皇 亦應修行。』擎奉レ佛像 經 教法師。天皇 詔 レ巷哥名レ伊奈米ノ大臣、修行レ茲法。故 佛法 始建 ${ }^{\vee}$ 大倭 $\left.{ }^{60}\right)$. Об этом же говорится в пространной надписи, сделанной в 5-й день 1-й луны 651 г. на основании шпиля пагоды храма Ганго̄-дзи (процитированной «Ганго̄дзи гаран энги»): «Во времена, когда страной Ямато из дворца Сикисима повелевал [император] Амэ-куни-оси-хараки Хиронива (государь Киммэй), а ему служил главный министр Сога по имени Инамэ, ван Сонмён из страны Пэкче сообщил императору: «Из всех законов Закон Будды - наилучший». Услышав эти слова, император и главный министр рекли: «Как прекрасно. Мы примем Закон Будды и утвердим его в стране Ямато»») [цит. по: 47, с. 423] (授塔露盤銘:『大和國 天皇斯歸斯麻宮治天下 名 阿末久爾意斯波羅岐比 里爾波ノ彌已等之 奉仕 巷宜 名 伊那米大臣ノ時、 百濟國ノ正明王上啓云:『萬法之中佛法最上也。 』是以 天皇 并大臣聞 食之宣: 『善哉。則受レ佛 法、造立レ倭國』61).

О событиях, связанных с распространением буддизма, говорится в отрывках из «Дзэнкодзи энги» (процитированных в св. 3-м «Фусо̄-рякки») [3, с. 60]: «"Дзэнкодзи энги" говорит: в правление государя (сумэра-микото) Ама-куни-оси-хараки Хиронива [Киммэя], [в] 13-й год мидзуноэ-саpy (9-й год цикла) (552 г. [54, с. 134]), 10-ю луну, 13-й день, из государства Кудара (кор. Пэкче-кук) [статуя] (будды) Амида [и] три категории высокочтимого ${ }^{62}$, плывя по волнам ${ }^{63}$, прибыли в знаменитую гавань Нанива области Сэццу в Японской стране» (善光寺緣記 云、天國排開廣庭 [欽明]天 皇治十三年壬申十月十三日。從百濟國、阿彌

\footnotetext{
55 т.е. буддийские сутры (Nihon-koku genhō zen'aku ryōiki, c. 74, п. 2).

56 日本國現報善惡靈異記. 群書類従. 東京: 経済雑誌社, 1902. 第十六輯. 頁20. (Nihon-koku genhō zen’aku ryōiki. Gunsho ruijū. Tōkyō: Keizai zasshi-sha, 1902. Iss. 16. P. 20).

57 阿彌陀佛 Амитабха - одна из трех форм Будды (三身, санскр. trikāya) (БКРС, II, с. 1066).

58 觀音 будд. кит. Гуань-инь, богиня Милосердия (Авалокитешвара) (БКРС, IV, с. 460).

59 扶桑略記. 国史大系. 東京: 経済雑誌社, 1901. 第六巻. 頁483. (Fusō-ryakki. Kokushi-taikei. Tōkyō: Keizai zasshi-sha, 1901. Vol. VI. P. 483); 扶桑略記. 史籍集覧. 東京: 近藤出版部, 1906. 第一巻. 頁28. (Fusō-ryakki. Shiseki shūran. Tōkyō : Kondō shuppanbu, 1906. Vol. I. P. 28).

60 元興寺伽藍縁起. 大日本仏教全書. 東京: 仏書刊行会, 1922. 第118巻. 頁144. (Gangōji garan engi. Dai-nihon bukkyō zensho. Tōkyō: Bussho kankōkai, 1922. Vol. 118. P. 144); 元興寺丈六光背銘. 假名源流孝. 東京: 國定教科書共同販売所, 1911. 第1巻. 頁36. (Gangō-ji jō-roku kōhaimei. Kana-genryū-kō. Tōkyō: Kokutei kyōkasho kyōdō hanbaijo, 1911. Vol. I. P. 36); 丈六光銘. 元興寺伽藍縁起并流記資財 帳.『寧樂遺文』中巻、東京堂出版. (Jōroku kōmei. Gangōji garan engi narabi-ni ruki shizaichō. Neiraku ibun ("The flourishing unpublished compositions", 2nd scroll. Tōkyō: Tōkyō-dodehan)). Режим доступа: http://home.p07.itscom.net/strmdrf/kyusyu _ref23.htm (дата обращения: 28.05.2018).

61 元興寺伽藍縁起. 大日本仏教全書. 東京: 仏書刊行会, 1922. 第118巻. 頁143. (Gangōji garan engi. Dai-nihon bukkyō zensho. Tōkyō: Bussho kankōkai, 1922. Vol. 118. P. 143); 元興寺露盤銘. 假名源流孝. 東京: 國定教科書共同販売所, 1911. 第1巻. 頁30-31. (Gangō-ji roban-mei. Kana-genryū-kō. Tōkyō: Kokutei kyōkasho kyōdō hanbaijo, 1911. Vol. I. P. 30-31); 元興寺露盤記. 大日本金石史. 大阪: 好尚会 出版部, 1921. 第一巻. 頁15. (Gangō-ji roban-ki. Dai-nihon kinseki-shi. Ōsaka: Kōshō-kai shuppan-bu, 1921. Vol. I. P. 15).

62 三尊 яп. сансон, кит. сарньиз унь - будды, каноны, монашествующие (БКРС 7, II, с. 31).

63 浮浪 яп. фуро - букв. скитаясь (БКРС, III, с. 13) [50, с. 355].
} 
陀 尊 浮浪來、著日本國攝津國難波津 $\left.{ }^{64}\right) \quad(\Phi y c \overline{-}-$ рякки, св. 3-й, Киммэй, 13-й год, 10-я луна, цитата из «Дзэнкодзи энги»). Подобная информация содержится в «Кэнкодзи энги» и в других, менее известных «храмовых историях» [3, с. 60].

Поэтому 552 г. можно признать датой официального принятия буддизма при дворе государя Ямато не принцем Хиронива, а теперь уже, разумеется, государем Киммэем (хотя неофициально буддизм начал распространяться в Японии раньше - в первой половине VI в. [1]).

\section{Влияние буддизма на приобщение японщев к письменной культуре}

Дж. Б. Сэнсом указывает, что, несомненно, введение буддизма сильно стимулировало использование письменности, когда японцы с энтузиазмом принялись копировать сутры [56, с. 87, п. 1]. Правда, ныне ни одной копии сутр или китайской классической литературы, привезенных в Японию с континента в период до конца VI в., не сохранилось [13, р. 159].

Л. М. Ермакова отмечает, что чтение монахами буддийских сутр, произносимых по китайским японизированным чтениям, и сейчас непонятно верующим на слух, да и в общем на взгляд тоже китайский язык сутр невозможно было прочитать без длительной специальной подготовки. То есть можно сказать, что для японцев сутра представляет собой ритмизированный магический текст, понимание которого невозможно и не ожидается без многолетнего периода ученичества [57, с. 66, п. 17]. Наличие в буддизме письменного канона предполагало, что японские монахи должны были в той или иной степени овладевать письменностью, которая давала им доступ к письменным источникам как конфессиональных, так и внеконфессиональных знаний. Признание же ими Китая в качестве своей духовной родины способствовало поддержанию постоянных контактов с материком. В этом отношении японские монахи всегда проявляли бо́льшую активность, чем общество в целом $[58$, c. $38 ; 59$, с. $94 ; 3$, с. $67 ; 13$, p. 454$]$

C середины VI в. культурное влияние континента вызвало в Японии новую волну интереса к образованию. С того времени книги и учёные в области буддизма, конфуцианства, даосизма, литературы и истории стали высоко цениться в Японии [13, p. 159, 171]. Из «Нихон-сёки» известно, что в се- редине VI в. в Ямато в период до 2-й луны 554 г. находились буддийский монах Тосим и еще шесть монахов, а также «старший учёный» ${ }^{65}$ Пятикнижия Ма Чонъан [46, с. 57] (Нихон-сёки, св. 19-й, Киммэй, 15-й год правления, 2-я луна). В 553 г. специально отправленное в Пэкче посольство привезло из Кореи книги по медицине, магии и календарь. «[553 г.] 6-я луна. Ути-но оми отправлен в Пэкче послом < ..> Он преподнёс [вану] < ..> (подарки). В послании ${ }^{66}$, $<\ldots>$ кроме того, говорилось: "Смени лекарей, прорицателей и знатоков календаря ${ }^{67}$. Настало время для замены людей, указанных выше. Пусть их сменщики присоединятся к [нашему] послу. Пусть будут также присланы книги по прорицанию ${ }^{68}$, календари ${ }^{69}$ и разные лекарства"» [46, с. 54-55] (Нихон-сёки, св. 19-й, Киммэй, 14-й год, 6-я луна). Исследователи отмечают особые требования, выдвигаемые японским правителем, касающихся поставок книг и присылки учёных - специалистов в разных отраслях знаний, глубокий интерес к китайской учености [13, p. 171]. В 7-й день 8-й луны 553 г. государь Пэкче прислал большой доклад (кит. бя̆о), который был прочитан при дворе Киммэя ${ }^{70}[46$, с. 55-56; 19, p. $119 ; 52$, р. 69-70].

На следующий год (в 554 г.) в ответ на просьбу Киммэя из Пэкче был прислан специалист по календарю (яп. рэки-хакасэ) [60, с. 192; 19, р. 119; 52, p. 68] Ван Посон, старший ученый Пятикнижия (五 經博士 кит. $y$-изйн бо́'шй, яп. го-кё-но хакасэ [46, c. $83 ; 19$, p. $120 ; 52$, p. 72]) Ван Югви (он заменил прежнего знатока Пятикнижия - Ма Чонъана), профессор прорицания Ван Торян, профессор медицины Ванъю Нынтха, профессоры лекарственных дел Пон Нянпхун и Чон Ютха, буддийский монах Тамхе по главе восьми других монахов (они заменили монаха Тосима и шестерых других монахов) [46, с. 57; 13, p. 171] (Нихон-сёки, св. 19-й, Киммэй, 15-й год, 2-я луна). Таким образом, постепенно японцы познакомились с новой системой счета лет и месяцев [61, 頁157]. М. В. Воробьев считает, что это были буддийские календари [49, с. 227]. А. Р. Садокова полагает, что данный календарь 553 г. стал первым официальным японским календарем, и просуществовал он вплоть до 604 г. Однако более подробные сведения об этом календаре отсутствуют [62, с. 162].

В связи с этим следует обратить внимание на сообщение «Мунаката дай-босацу го-энги», в котором отмечается: «В 1-й год Хо̄сэй [554 г.] из Великого

64 扶桑略記. 国史大系. 東京: 経済䧱誌社, 1901. 第六巻. 頁483. (Fusō-ryakki. Kokushi-taikei. Tōkyō: Keizai zasshi-sha, 1901. Vol. VI. P. 483); 扶桑略記. 史籍集覧. 東京: 近藤出版部, 1906. 第一巻. 頁28. (Fusō-ryakki. Shiseki shūran. Tōkyō : Kondō shuppanbu, 1906. Vol. I. P. 28).

65 博士 кит. бо́ 'uй, яп. хакасэ (БКРС, III, с. 58).

${ }^{66}$ указе (勑 вм. 敕 яп. микотонори, кит. чй (БКРС, III, с. 562; Nihon-shoki, p. 79)) государя Киммэя правителю Пэкче.

67 曆ノ博士 яп. коёми-но хакасэ [46, с. 77; 19, p. 119].

68 卜書 яп. ура-но фуми (Nihon-shoki, p. 79).

69 曆本 яп. коёми-но хон - досл. «книги по календарям» (Nihon-shoki, p. 79).

70 日本書紀 (国史大系)。東京：吉川弘文館，1957。第一部。第2巻。頁79-80. (Nihon-shoki (Kokushi-taikei). Tōkyō: Yoshikawa kobunkan, 1957. Part I. Vol. II. P. 79-80). 
Китая [тексты] буддийского Закона впервые (хадзимэтэ) были перевезены [в Японию]» (法清元年 仁自 大唐 仏法 始天 渡 $レ 也^{71}$ ) (Мунаката дай-босацу го-энги, Хо̄сэй, 1-й год). Сходная информация дана в «Ни-тю̄-рэки»: «[Девиз правления] Хо̄сэй [продолжительность] четыре года (начало эры [приходится] на год киноэ-ину, 11-й год цикла [554г.]; [в этом году] тексты [буддийского] Закона ${ }^{72}$ [из] Китая переправили буддийские монахи, передавшие глубочайшую мудрость ${ }^{73}$ » (法清四年 (554)【元 レ甲戌、法文文 唐 渡レ僧 善知傳】 $\left.{ }^{74}\right)$ (Ни-тю̄-рэки, “Нэндай-рэки”, Хо̄сэй, 1-й год, киноэ-ину).

Степень овладения китайской письменностью при дворе Ямато в середине IV в. может характеризовать следующий факт. Анализ сведений «Нихон-сёки» показал, что в данном источнике можно выделить (по характеру материалов) две части. Первую - традиционную часть (до середины правления Киммэя, т.е. до 555 г.); и вторую - историческое повествование официально-китайского типа (начиная со второй половины царствования Киммэя)
[49, с. 118]. Следовательно, с середины 50-х гг. VI в. в Японии при дворе Ямато появились люди, способные составлять исторические записи правильным китайским языком.

\section{Заключение}

Таким образом, утверждения некоторых китайских династийных историй об отсутствии письменности в Ямато до распространения буддизма не подтверждаются ни эпиграфическими, ни историческими материалами. Распространение буддизма и его письменных текстов в 40-50-е гг. VI в. стимулировали в Японии усиление процесса обучения письму и использования письменности, что повлекло за собой отказ от традиционных способов фиксации и передачи информации при помощи узелкового письма и резов. Всё это в совокупности привело к тому, что во второй половине VI в. в определенных кругах Японии (прежде всего, среди буддистов и учёных) китайская письменность была освоена уже на должном уровне.

\section{Литература}

1. Суровень Д. А. Роль китайских переселенцев из государств Лян и Северная Вэй в распространении буддизма в Японии в 20-е - 30-е годы VI века // Китай: история и современность: материалы V Междунар. науч.-практ. конф. (Екатеринбург, 22-24 ноября 2011 г.) Екатеринбург: Изд-во Уральского университета, 2012. C. $133-142$.

2. Мещеряков А. Н. История как метаязык раннеяпонской словесности // Дискуссионные проблемы японской истории. М.: Наука, 1991. С. 112-126.

3. Мещеряков А. Н. Древняя Япония: буддизм и синтоизм. М.: Наука, 1987. 192 с.

4. Бичурин Н. Я. Собрание сведений о народах, обитавших в Средней Азии в древние времена. М.-Л.: Изд-во АН СССР, 1950. Т. II. 336 с.

5. Sources of the Japanese tradition / comp. Ryūsaku Tsunoda, Wm. Theodore de Bary, Donald Keene. N. Y.London: Routledge and Kegan Paul, 1965. Vol. I. xxvi, 928 p.

6. Japan in the Chinese dynastic histories: Later Han through Ming Dynasties / transl. Ryusaka Tsunoda, ed. L. Carrington Goodrich. Perkins Asiatic Monographs, no. 1. South Pasadena, 1951. 187 p.

7. Пак М. Н. Очерки по историографии Кореи. М.: Наука, 1987. 148 с.

8. Джарылгасинова Р. Ш. Этногенез и этническая история корейцев по данным эпиграфики. М.: Наука, 1979. $182 \mathrm{c}$.

9. Мещеряков А. Н. «Нихон-сёки»: историческая мысль и культурный контекст // Нихон-сёки: Анналы Японии. СПб.: Гиперион, 1997. Т. І. С. 71-110.

10. Воробьев М. В., Соколова Г. А. Очерки истории науки, техники и ремесла в Японии. М.: Наука, 1976. $230 \mathrm{c}$.

11. История Японии. Т. І. С древнейших времен до 1868 года / отв. ред. А. Е. Жуков. М.: Ин-т востоковедения РАН, 1999. 659 с.

12. Мещеряков А. Н., Грачёв М. В. История древней Японии. СПб.: Гиперион, 2002. 512 с.

71 宗像大菩薩御縁起. 宗像郡誌. 中編. 若松: 深田千太郎, 1944. 頁376. (Munakata daibosatsu go-engi. Munakata-gun-shi. Vol. 2. Wakamatsu: Fukada Sentarō, 1944. P. 376); 大宝以前の逸年号一逸年号史料集成 (Kawanishi Yoshihiro. Taihō-izen-no itsu nengō shiryō shūsei). Режим доступа: http://www2.odn.ne.jp/ cbe66980/Main/Appendix.htm (дата обращения: 28.05.2018).

72 法文文 др.-яп. нори-но пумибуми, совр.-яп. хо̄бунбун, кит. фӑ'вэ́ньвэ́нь (Ни-тю̄-рэки, с. 36; Kawanishi Yoshihiro. Taihō-izen-no itsu nengō shiryō shūsei), где 法文 кит. фӑ̆'

73 善知傳 (Ни-тю̄-рэки, с. 36; Kawanishi Yoshihiro. Taihō-izen-no itsu nengō shiryō shūsei); ср.: 善知識 кит. ша̀нь-чжи-ци́ - будд., даос. глубочайшую мудрость познавший, глубокомудрый (об учёном монахе) (БКРС, II, с. 464).

74 二中歴. 史籍集覧. 東京: 近藤出版部, 1926. 第二十三冊. 頁36. (Ni-chū-reki. Shiseki shūran. Tōkyō: Kondō shuppanbu, 1926. Vol. 23. P. 36); 大宝以前の逸年号一逸年号史料集成 (Kawanishi Yoshihiro. Taihō-izen-no itsu nengō shiryō shūsei). Peжим доступа: http:// www2.odn.ne.jp/ cbe66980/Main/Appendix.htm (дата обращения: 28.05.2018). 
13. The Cambridge history of Japan. Vol. I: Ancient Japan. Ed. Delmer M. Brown. Cambridge-N. Y.: Cambridge University Press, 1993. 602 p.

14. Hall J. W. Japan: from prehistory to modern times. Michigan: Center for Japanese studies, Univ. of Michigan, 1991. 397 p.

15. 土肥 俊郎, 河西 敏雄, 中島 利治, 佐光 大和. 埼玉古墳加の出土品 (金錯銘鉄剣) 再現加工に関 する研究 // 日本機械学会文集 (C 編). 1995. 61巻. 591号. 頁375-381.

16. 上田 正明, 森 浩一, 山田 宗睦. 日本古代史. 東京: 筑摩書房, 1980. viii, 334頁.

17. 松本 清張. 清張通史. 東京: 講談社, 1977. 第二巻. 280頁.

18. 山尾 幸久. 日本古代王権形成史論. 東京: 岩波書店, 1983. 486, 15 頁.

19. Hong Wontack. Paekche of Korea and the origin of Yamato Japan. Seoul: Kudara International, 1994. 328 p.

20. Murayama Shichiro, Miller R. A. The Inariyama tumulus sword inscription // Journal of Japanese studies. 1979. Vol. 5. № 2. P. 405-438.

21. 日本の建国. 東京: 東京大学出版會, 1957. 246頁.

22. 日本全史. 東京: 東京大学出版会, 1958. 第一冊. 321頁.

23. 古代。平安. 東京, 1976. 一部. 115頁.

24. 中田 興吉. 大王と大后－その成立と性格 // 日本歴史. 2007. 第708号. 頁1-16.

25. 中田 興吉. 発生期のミヤケと王権 // 日本歴史. 2011. 第759号. 頁1-16.

26. 吉村 武彦. 六世紀における氏・姓制の研究 - 氏の成立を中心として // 明治大学人文科学研究所紀 要. 1996. 第39冊. 頁321-332.

27. 北村 優季. 記紀にみえる日本古代の宮号 // 山形大学歴史・地理・人類学論集. 2003. 第4号. 頁 1-12.

28. 川本 芳昭. 倭国について対外交涉の変遷について// 史淵 (九州大学). 2006. 第143号. 頁27-64.

29. 堤 克彦.「江田船山古墳」の被葬者と「鞠智城」築城の背景をさぐる// 研究紀要（熊本県高等学校地 歴.公民科研究会). 2010. 第40号. 頁26-84.

30. Черевко К. Е. «Кодзики» («Запись о деяниях древности») VIII в. и становление японского этноса, его языка и письменности. М.: Дип. академия МИД России, 2002. 336 с.

31. Суровень Д. А. Китайско-корейские переселенцы аябито в Японии начала V века // Известия Уральского государственного университета. Серия 2: Гуманитарные науки. 2011. № 1. С. 169-194.

32. Суровень Д. А. Влияние китайско-корейских переселенцев аябито на государственность и культуру Ямато V в. // Известия Уральского государственного университета. Серия 2: Гуманитарные науки. 2011. № 2. С. 20-35.

33. Суровень Д. А. Японо-корейские и японо-китайские отношения и внешняя политика государства Ямато в конце 50-х - 70-е годы V века // Уральское востоковедение: Международный альманах. 2008. № 3. С. 4-29.

34. Суровень Д. А. О времени начала использования письменности при дворе государства Ямато // Актуальные вопросы востоковедения: проблемы и перспективы: материалы заочной науч.-практ. конф. / отв. ред. Н. В. Гурьян, О. А. Трофименко. Уссурийск: Изд-во УГПИ, 2010. С. 120-125.

35. Суровень Д. А. О распространении навыков письма при дворе Ямато во второй половине IV века // Актуальные вопросы востоковедения: проблемы и перспективы: материалы II Междунар. заочной науч.практич. конф. / отв. ред. Н. В. Гурьян, О. А. Трофименко. Уссурийск: Изд-во ДВФУ, 2011. С. 176-188.

36. Ким Бусик. Самкук саги. М.: Изд-во вост. лит., 1959. Т. I. 384, VI, 202, VII с.

37. 野口 義廣.「防長学」事始作 - 『大内盛衰記』に見る大内氏の古代伝承を考える//山口県立大学国 際文化学部紀要. 1997. 第3号. 頁27-64, 101.

38. Seeley Ch. A history of writing in Japan. Leiden-N. Y.-Kobenhavn-Köln: E. J. Brill, 1991. 243 p.

39. Суровень Д. А. Первые исторические сочинения и использование письменности в Японии конца V первой половины VI веков // Актуальные вопросы востоковедения: проблемы и перспективы: материалы V Междунар. заочной науч.-практ. конф. / отв. ред. Н. В. Гурьян, О. А. Трофименко. Владивосток: ДВФУ, 2014. С. $86-106$.

40. Тихонов В. М. История Кореи: с древнейших времен до 1876 года. М.: Муравей, 2003. Т. I. 464 с.

41. Bowring R. J. The religious traditions of Japan, 500-1600. Cambridge: Cambridge university press, 2005. 485 p.

42. Сёдзан энги - Сказания о горах // Синто: путь японских богов / отв. ред. Е. М. Ермакова,

Г. Е. Комаровский, А. Н. Мещеряков. СПб.: Гиперион, 2002. Т. ІІ. С. 216-225.

43. Игнатович А. Н. Буддизм в Японии: очерк ранней истории. М.: Наука, 1987. 319 с.

44. Синто: путь японских богов / отв. ред. Е. М. Ермакова, Г. Е. Комаровский, А. Н. Мещеряков. СПб.: Гиперион, 2002. T. II. 496 с.

45. 三橋 正. 仏教受容と神祇信仰の形成: 神仏習合の源流 // 宗教研究. 2007. 第81(2)号. 頁333-358 (123-148).

46. Нихон-сёки: Анналы Японии; пер. и комм. Е. М. Ермаковой, А. Н. Мещерякова. СПб.: Гиперион, 1997. T. II. 432 c. 
47. Буддизм в Японии / отв. ред. Т. П. Григорьева. М.: Наука, 1993. 704 с.

48. Кодзики: Записи о деяниях древности; пер., предисл. и комм. Е. М. Ермаковой, А. Н. Мещерякова.. СПб.: Шар, 1994. Т. II. 256 с.

49. Воробьев М. В. Япония в III-VII веках. М.: Наука, 1980. 344 с.

50. Фельдман-Конрад Н. И. Японско-русский учебный словарь иероглифов. М.: Русск. яз., 1977. 680 с.

51. Суровень Д. А. Способы фиксации, сохранения и передачи исторической информации в период раннего Ямато // Актуальные вопросы востоковедения: проблемы и перспективы: материалы III Междунар. заочной науч.-практ. конф. / отв. ред. Н. В. Гурьян, О. А. Трофименко. Уссурийск: Изд-во ДВФУ, 2012. С. 178-189.

52. Nihongi: Chronicles of Japan from the earliest times to A.D. 697; transl. by W. G. Aston. London: Allen, 1956. Part II. 444 p.

53. Тихонов В. М. История каяских протогосударств (вторая половина V в. - 562 г.). М.: Вост. лит. РАН, 1998. $256 \mathrm{c}$.

54. Цыбульский В. В. Лунно-солнечный календарь стран Восточной Азии. М.: Наука, 1987. 384 с.

55. Нихон-рёики: Японские легенды о чудесах; пер., предисл. и коммент. А. Н. Мещерякова. СПб.: Гиперион, 1995. $256 \mathrm{c.}$

56. Сэнсом Дж. Б. Япония: Краткая история культуры. СПб.: Евразия, 1999. 576 с.

57. Ермакова Л. М. «Нихон-сёки» - культурный полицентризм и выбор культуры // Нихон-сёки: Анналы Японии; пер. и комм. Е. М. Ермаковой, А. Н. Мещерякова. СПб.: Гиперион, 1997. Т. І. С. 5-70.

58. Мещеряков А. Н. Внешний фактор в культуре Японии // Азия - диалог цивилизаций. СПб.: Гиперион, 1996. С. 17-55.

59. Мещеряков А. Н. «Нихон сёки»: историческая мысль и культурный контекст // Нихон-сёки: Анналы Японии. СПб.: Гиперион, 1997. Т. І. С. 71-110.

60. Конрад Н. И. Япония. Народ и государство. Исторический очерк // История Японии. М.: Евролинц Русская панорама, 2004. С. 158-340.

61. 佐野 大和. 日本のあけぼの. 東京: 小峰書店, 1959. 282頁.

62. Садокова А. Р. Официальный и народный земледельческий календари японцев // Календарь в культуре народов мира. М.: Наука, 1993. С. 162-170.

\title{
INFLUENCE OF BUDDHISM ON THE EXPANSION OF WRITING IN THE MID SIXTH CENTURY YAMATO \\ Dmitriy A. Surowen ${ }^{a}$ @
}

\author{
${ }^{a}$ Ural State Law University, 21, Komsomolskaya St., Ekaterinburg, Russia, 620137 \\ @Yamato.ur@mail.ru
}

Received 07.07.2018. Accepted 05.12.2018.

Keywords: ancient Japan, talking knots, cuts on wooden plates, prince Hironiwa, Kimmei, Song-wang

\begin{abstract}
The article features the influence of Buddhism, which appeared in Japan in the first half of the VI century, on the expansion of writing and written culture in Yamato. The author believes that the Chinese dynastic stories underestimated the expansion of writing in Japan during the VI century in their wish to link the appearance of the written language with Buddhism, which contradicts the finds of ancient Japanese epigraphic inscriptions on swords and mirrors made in the $\mathrm{V}$ century. The confusion in the Chinese sources probably arose from the ancient tradition of talking knots and cuts on wooden plates in the early VI century. Yamato had to refuse from this practice when Buddhism entered Japan in the early VI century. First, Buddhism was introduced at the court of the unrecognized Yamato ruler, prince Hironiwa (future Kimmei) in 538 A.D. It was officially recognized during his rule in 552 A.D., which was confirmed by the Chinese dynastic histories. To read Buddhist literature and write in good Chinese, new Japanese adepts and scientists had to master thieroglyphic writing.
\end{abstract}


For citation: Surowen D. A. Vliianie buddizma na rasprostranenie pis'mennosti v Iamato v seredine VI v. [Influence of Buddhism on the Expansion of Writing in the Mid Sixth Century Yamato]. Bulletin of Kemerovo State University, no. 4 (2018): 79-92. DOI: https://doi.org/10.21603/2078-8975-2018-4-79-92

\section{References}

1. Suroven D. A. Rol' kitaiskikh pereselentsev iz gosudarstv Lian i Severnaia Vei v rasprostranenii buddizma v Iaponii v 20-e - 30-e gody VI veka [The role of Chinese immigrants from the Liang state and the Northern Wei state in the spread of Buddhism in Japan in 520s-530s A.D.]. Kitai: istoriia i sovremennost': materialy VMezhdunar. nauch.-prakt. konf. (Ekaterinburg, 22-24 noiabria 2011 g.) [China: Past and Present: Proc. V Intern. Sci.-Prac. Conf. (Yekaterinburg, November 22-24, 2011)]. Ekaterinburg: Izd-vo Ural'skogo universiteta, 2012, $133-142$.

2. Meshcheriakov A. N. Istoriia kak metaiazyk ranneiaponskoi slovesnosti [History as metalanguage of the early Japanese literature]. Diskussionnye problemy iaponskoi istorii [Discussion problems of Japanese history]. Moscow: Nauka, 1991, 112-126.

3. Meshcheriakov A. N. Drevniaia Iaponiia: buddizm i sintoizm [Ancient Japan: Buddhism and Shintoism]. Moscow: Nauka, 1987, 192.

4. Bichurin N. Ia. Sobranie svedenii o narodakh, obitavshikh v Srednei Azii v drevnie vremena [Collecting information about the peoples living in Central Asia in ancient times]. Moscow-Leningrad: Izd-vo AN SSSR, vol. II (1950): 336.

5. Sources of the Japanese tradition. Comp. Ryūsaku Tsunoda, Wm. Theodore de Bary, Donald Keene. N. Y.London: Routledge and Kegan Paul, vol. I (1965): xxvi, 928.

6. Japan in the Chinese dynastic histories: Later Han through Ming Dynasties. Transl. Ryusaka Tsunoda. Ed. Carrington Goodrich L. Perkins Asiatic Monographs, no. 1. South Pasadena, 1951, 187.

7. Pak M. N. Ocherki po istoriografii Korei [Notes on Korean historiography]. Moscow: Nauka, 1987, 148.

8. Dzharylgasinova R. Sh. Etnogenez i etnicheskaia istoriia koreitsev po dannym epigrafiki [Ethnogenesis and ethnic history of Koreans according to an epigraphics]. Moscow: Nauka, 1979, 182.

9. Meshcheriakov A. N. «Nikhon-sëki»: istoricheskaia mysl' i kul'turnyi kontekst [Nihon-shoki: historical thought and cultural context]. Nikhon-sëki: Annaly Iaponii [Nihon-shoki: Annals of Japan]. Saint-Petersburg: Giperion, vol. I (1997): 71-110.

10. Vorob'ev M. V., Sokolova G. A. Ocherki istorii nauki, tekhniki i remesla v Iaponii [Notes on the history of science, equipment, and craft in Japan]. Moscow: Nauka, 1976, 230.

11. Istoriia Iaponii. T. 1. S drevneishikh vremtn do 1868 goda [History of Japan. Vol. 1. From the most ancient times to 1868]. Ed. Zhukov A. E. Moscow In-t vostokovedeniia RAN, 1999, 659.

12. Meshcheriakov A. N., Grachev M. V. Istoriia drevnei Iaponii [History of ancient Japan]. Saint-Petersburg: Giperion, 2002, 512.

13. The Cambridge history of Japan. Vol. I: Ancient Japan. Ed. Delmer M. Brown. Cambridge-N. Y.: Cambridge University Press, 1993, 602.

14. Hall J. W. Japan: from prehistory to modern times. Michigan: Center for Japanese studies, Univ. of Michigan, 1991, 397.

15. Doi Toshirō, Kasai Toshio, Nakajima Toshiharu, Samitsu Yamato. Saitama-kofun-kara-no sutsudohin (kinsaku-mei tetsuken)-no saigen kakō-ni kan-suru kenkū. Nihon kikai gakkai bunshū ("C" hen), 61, no. 591 (1995): 375-381.

16. Ueda Masaaki, Mori Kōichi, Yamada Munemutsu. Nihon kodai-shi. Tōkyō: Chikuma shobo, 1980, viii, 334.

17. Matsumoto Seichō. Seichō-tsūshi. Tōkyō: Kōdansha, vol. II (1977): 280.

18. Yamao Yukihisa. Nihon kodai ōken-keisei shiron. Tōkyō: Iwanamishoten, 1983, 486, 15.

19. Hong Wontack. Paekche of Korea and the origin of Yamato Japan. Seoul: Kudara International, $1994,328$.

20. Murayama Shichiro, Miller R. A. The Inariyama tumulus sword inscription. Journal of Japanese studies, 5, no. 2 (1979): 405-438.

21. Nihon-no kengoku. Tōkyō: Tōkyō-daigaku shuppankai, 1957, 246.

22. Nihon zenshi. Tōkyō: Tōkyō-daigaku shuppankai, vol. I (1958): 321.

23. Kodai. Heian. Tōkyō, part I (1976), 115.

24. Nakada Kōkichi. Ō-kimi to ō-kisaki - sono seiritsu to seikaku. Nihon rekishi, no. 708 (2007): 1-16.

25. Nakada Kōkichi. Hassei-ki-no miyake to ōken. Nihon rekishi, no. 759 (2011): 1-16.

26. Yoshimura Takehiko. Roku-seiki-ni okeru uji-kabane-sei-no kenkū - uji-no seiritsu-wo Chūshin-to. Meiji-daigaku jimbun-kagaku kenkūjo kiyō, vol. 39 (1996): 321-332.

27. Kitamura Masaki. Ki-ki-ni mieru nihon-kodai-no miya-gō. Yamagata-daigaku rekishi, chiri, jinruigaku ronshū, no. 4 (2003): 1-12. 
28. Kawamoto Yoshiaki. Wa-koku-ni okeru taikaikōshō-no hensan-ni tsuite. Shien (Kyūshū-daigaku), no. 143 (2006): 27-64.

29. Tsutsumi Katsuhiko. "Eda Funayama-kofun"-no hisōsha to Kikuchi-shiro chikujō-no haikei-wo saguru. Kenkyū kiyō (Kumamoto-ken kōtōgakkō chi-reki kōminka kenkūkai), vol. 40 (2010): 26-84.

30. Cherevko K. E. "Kodziki" ("Zapis'o deianiiakh drevnosti") VIII v. i stanovlenie iaponskogo etnosa, ego iazyka i pis'mennosti ["Kojiki" ("Record on ancient matters") 8th century and formation of the Japanese ethnos, his language and writing]. Moscow: Dip. akademiia MID Rossii, 2002, 336.

31. Suroven D. A. Kitaisko-koreiskie pereselentsy aiabito v Iaponii nachala V veka [Chinese-Korean ayabito migrants in early 5th century Japan]. Izvestiia Ural'skogo gosudarstvennogo universiteta. Seriia 2: Gumanitarnye nauki = Izvestia. Ural Federal University Journal. Series 2. Humanities and Arts, no. 1 (2011): 169-194.

32. Suroven D. A. Vliianie kitaisko-koreiskikh pereselentsev aiabito na gosudarstvennost' i kul'turu Iamato V v. [Chinese-Korean Ayabito migrants' influence on the statehood and culture]. Izvestiia Ural'skogo gosudarstvennogo universiteta. Seriia 2: Gumanitarnye nauki = Izvestia. Ural Federal University Journal. Series 2. Humanities and Arts, no. 2 (2011): 20-35.

33. Suroven D. A. Iapono-koreiskie i iapono-kitaiskie otnosheniia i vneshniaia politika gosudarstva Iamato $\mathrm{v}$ kontse 50-kh - 70-e gody V veka [The Japanese-Korean and Japanese-Chinese relations and foreign policy of the Yamato state in the late 450s - 470s A.D.]. Ural'skoe vostokovedenie: Mezhdunarodnyi al'manakh = Ural Survey of Oriental Studies, no. 3 (2008): 4-29.

34. Suroven D. A. O vremeni nachala ispol'zovaniia pis'mennosti pri dvore gosudarstva Iamato [About time of the beginning of use of writing at the Court of the Yamato state]. Aktual'nye voprosy vostokovedeniia: problemy i perspektivy: materialy zaochnoi nauch.-prakt. konf. [Actual questions of Oriental studies: problems and prospects: Proc. correspondence Sci.-Prac. Conf.]. Ed. Guryan N. V., Trofimenko O. A. Ussuriisk: Izd-vo UGPI, 2010, $120-125$.

35. Suroven D. A. O rasprostranenii navykov pis'ma pri dvore Iamato vo vtoroi polovine IV veka [On the propagation of writing skills at the Yamato court during the second half of the IV century]. Aktual'nye voprosy vostokovedeniia: problemy i perspektivy: materialy II Mezhdunar. zaochnoi nauch.-prakt. konf. [Actual questions of Oriental studies: problems and prospects: Proc. II Intern. correspondence Sci.-Prac. Conf.]. Ed. Guryan N. V., Trofimenko O. A. Ussuriisk: Izd-vo DVFU, 2011, 176-188.

36. Kim Busik. Samkuk sagi [Samguk Saga]. Moscow: Izd-vo vost. lit., vol. I (1959): 384, VI, 202 , VII.

37. Noguchi Yoshihiro. "Bochō-gaku"-koto hajime - "Ōuchi seisui-ki"-ni miru Ōuchi-uji-no kodai denshōwo kangaeru. Yamaguchi-kenritsu kokusai bungaku-bu kiyō, no. 3 (1997): 27-64, 101.

38. Seeley Ch. A history of writing in Japan. Leiden-N. Y.-Kobenhavn-Köln: E. J. Brill, 1991, 243.

39. Suroven D. A. Pervye istoricheskie sochineniia i ispol'zovanie pis'mennosti v Iaponii kontsa V - pervoi poloviny VI vekov [The first historical compositions and use of writing in Japan of the late V - early VI centuries A.D.]. Aktual'nye voprosy vostokovedeniia: problemy i perspektivy: materialy V Mezhdunar. zaochnoi nauch.prakt. konf. [Actual questions of Oriental studies: problems and prospects: Proc. V Intern. correspondence Sci.Prac. Conf.]. Ed. Guryan N. V., Trofimenko O. A. Vladivostok: DVFU, 2014, 86-106.

40. Tikhonov V. M. Istoriia Korei: s drevneishikh vremen do 1876 goda [History of Korea: from the most ancient times to 1876]. Moscow: Muravei, vol. I (2003): 464.

41. Bowring R. J. The religious traditions of Japan, 500-1600. Cambridge: Cambridge university press, 2005,485 .

42. Sedzan engi - Skazaniia o gorakh [Shozan engi - Legends on mountains]. Sinto: put' iaponskikh bogov [Shinto - the way of the Japanese gods]. Ed. Ermakova E. M., Komarovskii G. E., Meshcheriakov A. N. SaintPetersburg: Giperion, vol. II (2002): 216-225.

43. Ignatovich A. N. Buddizm v Iaponii: ocherk rannei istorii [The Buddhism in Japan: outline of early history]. Moscow: Nauka, 1987, 319.

44. Sinto: put' iaponskikh bogov [Shinto - the way of the Japanese gods]. Ed. Ermakova E. M., Komarovskii G. E., Meshcheriakov A. N. Saint-Petersburg: Giperion, vol. II (2002): 496.

45. Mitsuhashi Masashi. Bukkyō-juyō to jingi-shinkō-no keisei: shimbutsu-shūgō-no gtnryū. Shūkyō-kenkyū, no. 81(2) (2007): 333-358 (123-148).

46. Nikhon-seki: Annaly Iaponii [Nihon-shoki: Annals of Japan]. Transl. and comm. Ermakova E. M., Meshcheriakov A. N. Saint-Petersburg: Giperion, vol. II (1997): 432.

47. Buddizm v Iaponii [The Buddhism in Japan]. Ed. Grigoyeva T. P. Moscow: Nauka, 1993, 704.

48. Kodziki: Zapisi o deianiiakh drevnosti [Kojiki: Records of ancient matters]. Saint-Petersburg: Shar, vol. II (1994): 256.

49. Vorob'ev M. V. Iaponiia v III-VII vekakh [Japan in III - VII centuries]. Moscow: Nauka, 1980, 344.

50. Fel'dman-Konrad N. I. Iaponsko-russkii uchebnyi slovar' ieroglifov [Japanese-Russian educational dictionary of hieroglyphs]. Moscow: Russk. iaz., 1977, 680. 
51. Suroven D. A. Sposoby fiksatsii, sokhraneniia i peredachi istoricheskoi informatsii v period rannego Iamato [The methods of fixation, preservation, and transmission of historical information in the early Yamato]. Aktual'nye voprosy vostokovedeniia: problemy i perspektivy: materialy III Mezhdunar. zaochnoi nauch.-prakt. konf. [Actual questions of Oriental studies: problems and prospects: Proc. III Intern. correspondence Sci.-Prac. Conf.]. Ed. Guryan N. V., Trofimenko O. A. Ussuriisk: Izd-vo DVFU, 2012, 178-189.

52. Nihongi: Chronicles of Japan from the earliest times to A.D. 697. Transl. Aston W. G. London: Allen, part II (1956): 444.

53. Tikhonov V. M. Istoriia kaiaskikh protogosudarstv (vtoraia polovina V v. - 562 g.) [History of Kaya proto-states (second half. V century - 562)]. Moscow: Vost. lit. RAN, 1998, 256.

54. Tsibul'skii V. V. Lunno-solnechnyi kalendar' stran Vostochnoi Azii [Lunisolar calendar of the countries of East Asia]. Moscow: Nauka, 1987, 384.

55. Nikhon-reiki: Iaponskie legendy o chudesakh [Nihon-ryōiki: Japanese legends of miracles]. Transl. and comm. Meshcheriakov A. N. Saint-Petersburg: Giperion, 1995, 256.

56. Sansom G. B. Iaponiia: Kratkaia istoriia kul'tury [Japan: Short cultural history]. Saint-Petersburg: Evraziia, 1999, 576.

57. Ermakova L. M. «Nikhon-seki» - kul'turnyi politsentrizm i vybor kul'tury [Nihon-shoki - cultural polycentrism and the choice of culture]. Nikhon-seki: Annaly Iaponii [Nihon-shoki: Annals of Japan]. Transl. and comm. Ermakova E. M., Meshcheriakov A. N. Saint-Petersburg: Giperion, vol. I (1997): 5-70.

58. Meshcheriakov A. N. Vneshnii faktor v kul'ture Iaponii [External factor in the culture of Japan]. Aziiadialog tsivilizatsii [Asia is a dialogue of civilizations]. Saint-Petersburg: Giperion, 1996, 17-55.

59. Meshcheriakov A. N. «Nikhon seki»: istoricheskaia mysl' i kul'turnyi kontekst [«Nihon-shoki»: historical thought and cultural context]. Nikhon-seki: Annaly Iaponii [Nihon-shoki: Annals of Japan]. Transl. and comm. Ermakova E. M., Meshcheriakov A. N. Saint-Petersburg: Giperion, vol. I (1997): 71-110.

60. Konrad N. I. Iaponiia. Narod i gosudarstvo. Istoricheskii ocherk [Japan. People and state. Historical outline]. Istoriia Iaponii [History of japan]. Moscow: Evrolints - Russkaia panorama, 2004, 158-340.

61. Sano Yamato. Nihon-no akebono. Tōkyō: Shōhō shoten, 1959, 282.

62. Sadokova A. R. Ofitsial'nyi i narodnyi zemledel'cheskii kalendari iapontsev [Official and national agricultural calendars of Japanese]. Kalendar'v kul'ture narodov mira [Calendar in the culture of the peoples of the world]. Moscow: Nauka, 1993, 162-170. 